\title{
Rapid assessment of the effect of ciprofloxacin on chromosomal DNA from Escherichia coli using an in situ DNA fragmentation assay María Tamayo ${ }^{1,2}$, Rebeca Santiso ${ }^{1,2}$, Jaime Gosalvez ${ }^{3}$, Germán Bou ${ }^{4}$ and José Luis Fernández*1,2
}

\begin{abstract}
Address: ${ }^{1}$ INIBIC-Complejo Hospitalario Universitario A Coruña, Unidad de Genética, As Xubias 84, 15006- A Coruña, Spain, ${ }^{2}$ Laboratorio de Genética Molecular y Radiobiología, Centro Oncológico de Galicia, Avda. de Montserrat s/n, 15009-A Coruña, Spain, ${ }^{3}$ Unidad de Genética, Facultad de Biología, Universidad Autónoma de Madrid, 28049-Madrid, Spain and ${ }^{4}$ INIBIC-Complejo Hospitalario Universitario A Coruña, Servicio de Microbiología, As Xubias, 84, 15006-A Coruña, Spain
\end{abstract}

Email: María Tamayo - mtamnov@canalejo.org; Rebeca Santiso - rsanbra@canalejo.org; Jaime Gosalvez - jaime.gosalvez@uam.es; Germán Bou - GermanBou@canalejo.org; José Luis Fernández* - JFerGar3@canalejo.org

* Corresponding author

Published: 13 April 2009

BMC Microbiology 2009, 9:69 doi:10.1 186/147|-2180-9-69
Received: 13 November 2008

Accepted: 13 April 2009

This article is available from: http://www.biomedcentral.com/147I-2180/9/69

(C) 2009 Tamayo et al; licensee BioMed Central Ltd.

This is an Open Access article distributed under the terms of the Creative Commons Attribution License (http://creativecommons.org/licenses/by/2.0), which permits unrestricted use, distribution, and reproduction in any medium, provided the original work is properly cited.

\begin{abstract}
Background: Fluoroquinolones are extensively used antibiotics that induce DNA double-strand breaks (DSBs) by trapping DNA gyrase and topoisomerase IV on DNA. This effect is usually evaluated using biochemical or molecular procedures, but these are not effective at the single-cell level. We assessed ciprofloxacin (CIP)-induced chromosomal DNA breakage in single-cell Escherichia coli by direct visualization of the DNA fragments that diffused from the nucleoid obtained after bacterial lysis in an agarose microgel on a slide.
\end{abstract}

Results: Exposing the E. coli strain TGI to CIP starting at a minimum inhibitory concentration (MIC) of $0.012 \mu \mathrm{g} / \mathrm{ml}$ and at increasing doses for $40 \mathrm{~min}$ increased the DNA fragmentation progressively. DNA damage started to be detectable at the MIC dose. At a dose of I $\mu \mathrm{g} / \mathrm{ml}$ of CIP, DNA damage was visualized clearly immediately after processing, and the DNA fragmentation increased progressively with the antibiotic incubation time. The level of DNA damage was much higher when the bacteria were taken from liquid LB broth than from solid LB agar. CIP treatment produced a progressively slower rate of DNA damage in bacteria in the stationary phase than in the exponentially growing phase. Removing the antibiotic after the 40 min incubation resulted in progressive DSB repair activity with time. The magnitude of DNA repair was inversely related to CIP dose and was noticeable after incubation with CIP at $0.1 \mu \mathrm{g} / \mathrm{ml}$ but scarce after $10 \mu \mathrm{g} / \mathrm{ml}$. The repair activity was not strictly related to viability. Four $E$. coli strains with identified mechanisms of reduced sensitivity to CIP were assessed using this procedure and produced DNA fragmentation levels that were inversely related to MIC dose, except those with very high MIC dose.

Conclusion: This procedure for determining DNA fragmentation is a simple and rapid test for studying and evaluating the effect of quinolones. 


\section{Background}

Fluoroquinolones are broad-spectrum antibacterial agents that are used widely to treat a variety of infections, such as gonococcal infections, osteomyelitis, enteric, and respiratory and urinary tract infections. Ciprofloxacin (CIP) is one of the most consumed fluoroquinolones worldwide [1,2]. The type II topoisomerases DNA gyrase and topoisomerase IV are the target of quinolones [3,4]. DNA gyrase is the preferential target in gram-negative bacteria such as E. coli, whereas topoisomerase IV is affected mainly in gram-positive bacteria [5]. These enzymes induce transient DNA double-strand breaks (DSBs) on bacterial chromosomes, which either introduce negative supercoiling, as in the case of DNA gyrase, or relax supercoiling and decatenate-replicated daughter chromosomes, as in the case of topoisomerase IV [3-5]. DNA gyrase is a tetramer with two GyrA and two GyrB subunits, and topoisomerase IV comprises two ParC and two ParE subunits. After DSB induction, the topoisomerase passes through the DNA duplex, seals the break, and releases DNA. During this process, a transient covalent link is established between the GyrA or the ParC subunits and the 5 ' end of each DNA break [3,5].

Quinolones bind rapidly to the DNA topoisomerases attached to DNA, producing ternary complexes comprising quinolone-topoisomerase-DNA. These complexes promptly block DNA replication and RNA transcription, an action that inhibits cell growth but does not clearly explain the cell killing by quinolones [5-7]. After formation of the ternary complex, a DSB is produced by topoisomerase, but bound quinolone inhibits the subsequent ligation of the DNA ends by trapping the topoisomerase on DNA to the GyrA or ParC proteins through a covalent bond of the 5' ends. These products are called cleaved complexes and are distributed throughout the bacterial chromosome. When using first-generation quinolones such us nalidixic acid, DSBs are constrained initially by the proteins from the cleaved complexes, and this process can be reversed by removing the quinolone, adding EDTA, or mild heat treatment. Cell killing is relatively slow, and the rate of killing seems to correlate with later massive chromosomal DNA fragmentation mediated by a putative protein suicide factor, whose synthesis may be blocked by chloramphenicol. In contrast, a high concentration of fluoroquinolones such as CIP or gatifloxacin produces rapid cell death and chromosomal DNA fragmentation, processes that are not protected by chloramphenicol and thus are protein synthesis independent $[6,7]$. In this case, DSBs from the cleaved complexes behave as irreversible products possibly because of the drug-mediated dissociation of topoisomerase subunits, and the DNA breaks are released from the protein constraint, thereby fragmenting the chromosome. Bactericidal antibiotics, including the quinolone norfloxacin, may induce the production of hydroxyl radicals that can cause extensive oxidative cellu- lar damage, including secondary DNA injury, which may contribute to bacterial death $[8,9]$.

Quinolone resistance results essentially from target modification caused by mutations in the genes encoding the subunits of DNA gyrase and topoisomerase IV, especially in the quinolone resistance-determining region (QRDR) [10-12]. Several mutations may coexist in the same or in different subunits and may produce high-level resistance. Changes in drug permeation or overexpression of efflux pumps may also be involved and, in combination with QRDR mutations, may contribute to high-level resistance [10-12]. Several recent studies indicate that target protection through plasmid-mediated quinolone-resistance genes also may play a significant role, and its prevalence is increasing worldwide [13]. The existence of fluoroquinolone-inactivating enzymes, like a variant of the gene that encodes aminoglycoside acetyltransferase AAC(6')Ib, has been proposed [14]. This enzyme variant would reduce the activity of both aminoglycosides and CIP.

Given the extended use of fluoroquinolones, especially CIP, a more thorough understanding of their activity is needed. Because chromosomal DNA fragmentation is the main mechanism that correlates with cell killing [5-7], it is the parameter of choice to assess fluoroquinolone activity. We have recently developed a kit that allows the simple and rapid assessment of the presence of fragmented DNA at the single-cell level in micro-organisms [15]. Cells immersed in an inert microgel on a slide are lysed, stained with a highly sensitive DNA fluorochrome, and visualized with a fluorescence microscope. The nucleoids with fragmented DNA are discriminated clearly by their peripheral halo of diffused DNA fragments. The greater the fragmentation, the greater the number of DNA spots and the greater the circular surface area of diffusion evident in this assay. Here we show the significant technical value of our procedure for determining the activity of fluoroquinolones, particularly for detecting chromosomal DNA damage and repair after CIP treatment in E. coli.

\section{Methods Cultures}

Chromosomal DNA fragmentation in situ was assayed in the TG1 E. coli strain, which was grown routinely in Luria Bertani (LB) broth (1\% Bacto-tryptone, $0.5 \%$ yeast extract, $0.5 \% \mathrm{NaCl}$ ) or on $\mathrm{LB}$ agar at $37^{\circ} \mathrm{C}$ in aerobic conditions. E. coli TG1 [genotype: F traD36 LacIq (lacZ)M15] proAB/ supE (hsdMmcrB)5(rkmk McrB) thi (lac-proAB). Cell growth in liquid cultures was evaluated by monitoring turbidity at $\mathrm{OD}_{600}$ using a spectrophotometer (Unicam 8625, Cambridge, UK). The minimum inhibitory concentration (MIC) was determined using the E-test (AB Biodisk, Solna Sweden) according to manufacturer's instructions. Viability was determined by colony counting after sequential dilutions and plating. To determine the 
percentage of viable cells, the number of cells seeded on the plate was counted using a cytometric camera.

\section{Experiments}

Three different experiments were performed with TG1 E. coli, all in triplicate. Typical experiments are presented. In the first, several colonies of TG1 E. coli were grown overnight on LB agar plates and then resuspended in LB broth at an $\mathrm{OD}_{600}$ of 0.05 and grown to an $\mathrm{OD}_{600}$ of 0.8 . The colonies were then incubated with $0,0.003,0.006,0.008$, $0.012,0.02,0.04,0.08,0.1,0.5$, or $1 \mu \mathrm{g} / \mathrm{ml}$ CIP (Sigma) in $15 \mathrm{ml}$ Falcon tubes containing $4 \mathrm{ml}$ of LB broth for 40 min at $37^{\circ} \mathrm{C}$ with aeration and shaking, and then processed to measure the chromosomal DNA fragmentation.

In the second experiment, TG1 E. coli was removed from culture in $\mathrm{LB}$ agar, resuspended in $\mathrm{LB}$ broth at an $\mathrm{OD}_{600}$ of 0.5 , and treated with $1 \mu \mathrm{g} / \mathrm{ml} \mathrm{CIP} \mathrm{in} \mathrm{LB} \mathrm{broth} \mathrm{at} 37^{\circ} \mathrm{C}$ with aeration and shaking. Aliquots were removed after 0, 5, 10, 15, 20,30 , and $40 \mathrm{~min}$ of incubation, and processed to measure DNA fragmentation. The time needed to prepare the microgel with the cells enclosed, before the slide was immersed in the lysing solution, was 8 min (see next section). In the results, this time must be added to each incubation period. To complete this experiment, TG1 E. coli were cultured in liquid LB broth at $37^{\circ} \mathrm{C}$ for $23 \mathrm{~h}$ with aeration and shaking, and the growth was monitored by measuring the turbidity $\left(\mathrm{OD}_{600}\right)$. The liquid cultures started at an $\mathrm{OD}_{600}$ of 0.05 . Aliquots were removed during the exponentially growing phase at $3 \mathrm{~h}$ (i.e., at an $\mathrm{OD}_{600}$ of 0.52 ) and during the stationary phase at $7 \mathrm{~h}\left(\mathrm{OD}_{600}: 1.20\right), 9 \mathrm{~h}\left(\mathrm{OD}_{600}: 1.52\right)$ and $23 \mathrm{~h}$ $\left(\mathrm{OD}_{600}: 1.84\right)$. At the end of each designated time, $1 \mu \mathrm{g} / \mathrm{ml}$ of CIP was added directly to the aliquot, and the aliquot was incubated at $37^{\circ} \mathrm{C}$ for 0 and $5 \mathrm{~min}$, and then processed to measure the DNA fragmentation.

In the third experiment, the micro-organisms were grown overnight on LB agar plates, resuspended in LB broth at an $\mathrm{OD}_{600}$ of 0.05 , grown to an $\mathrm{OD}_{600}$ of 0.8 , and then incubated with 10,1 , or $0.1 \mu \mathrm{g} / \mathrm{ml} \mathrm{CIP}$ in LB broth for $40 \mathrm{~min}$ at $37^{\circ} \mathrm{C}$. After the incubation, the CIP was removed from the medium by centrifuging the bacteria and washing in plain LB broth. The bacteria were incubated at $37^{\circ} \mathrm{C}$ in $\mathrm{LB}$ broth with aeration and shaking, and aliquots were removed at $0,1.5,3,4,5$, and $24 \mathrm{~h}$. For the $0.1 \mu \mathrm{g} / \mathrm{ml}$ dose of CIP, the bacteria were also incubated for $6 \mathrm{~h}$. One aliquot was used to measure the DNA fragmentation, and another was plated on $\mathrm{LB}$ agar at $37^{\circ} \mathrm{C}$ to measure the viability after $24 \mathrm{~h}$ of culture. Cultures without CIP and with CIP incorporated in the new LB medium added after washing after the initial CIP treatment were included and processed along with each dose and for the various incubation times.

\section{Bacterial strains with low CIP sensitivity}

Besides the experiments with TG1, DNA fragmentation was measured in four E. coli strains whose low sensitivity to CIP and underlying mechanisms are known. These included strains with mutations in the QRDR region from GyrA and ParC [16]. The isolates were C-15 (Ser83Leu from GyrA; CIP MIC $=0.25 \mu \mathrm{g} / \mathrm{ml}$ ); 1273 (Ser83Leu and Asp87Tyr from GyrA; CIP MIC: $8.0 \mu \mathrm{g} / \mathrm{ml}$ ), and 1383 (Ser83Leu and Asp87Tyr from GyrA together with Ser80Ile and Glu84Lys from ParC; CIP MIC: $128 \mu \mathrm{g} / \mathrm{ml}$ ), and the control strain $\mathrm{C}-20$ with no mutation in the QRDR region (CIP MIC: $0.007 \mu \mathrm{g} / \mathrm{ml}$ ). The strain J53 with the plasmid-mediated quinolone-resistance gene qnrA1 (CIP MIC: $0.25 \mu \mathrm{g} / \mathrm{ml}$ ) and its control strain J53 without the plasmid were also examined [17]. These strains were exposed to CIP at the MIC dose, at $10 \times$ and $100 \times$ the MIC dose, and at $0.5 \times$ and $0.25 \times$ the MIC dose for $40 \mathrm{~min}$ at $37^{\circ} \mathrm{C}$ in the exponentially growing phase, and DNA fragmentation was determined.

\section{Determination of DNA fragmentation}

The Micro-Halomax ${ }^{\circledast}$ kit for fluorescence microscopy (Halotech DNA SL, Madrid, Spain) was used. A thorough description has been published previously [15]. Essentially, an aliquot of each sample was diluted to a concentration of 5-10 million micro-organisms/ml in LB medium. The kit includes $0.5 \mathrm{ml}$ snap cap microfuge tubes containing gelled aliquots of low-melting point agarose. The tube was placed in a water bath at $90-100^{\circ} \mathrm{C}$ for about $5 \mathrm{~min}$ to melt the agarose completely and then placed in a water bath at $37^{\circ} \mathrm{C}$. Twenty-five microlitres of the diluted sample was added to the tube and mixed with the melted agarose. A $20 \mu \mathrm{l}$ aliquot of the sample-agarose mixture was pipetted onto a precoated slide, and the sample was covered with a $22 \mathrm{~mm} \times 22 \mathrm{~mm}$ coverslip. The slide was placed on a cold plate in the refrigerator $\left(4^{\circ} \mathrm{C}\right)$ for $5 \mathrm{~min}$ to allow the agarose to produce a microgel with the trapped intact cells inside. The coverslip was removed gently, and the slide was immediately immersed horizontally in $10 \mathrm{ml}$ of the lysing solution for $5 \mathrm{~min}$ at $37^{\circ} \mathrm{C}$. The slide was washed horizontally in a tray with abundant distilled water for $3 \mathrm{~min}$, dehydrated by incubating horizontally in cold $\left(-20^{\circ} \mathrm{C}\right)$ ethanol of increasing concentration $(70 \%, 90 \%$, and $100 \%)$ for 3 min each, and air-dried in an oven.

The dried slide was incubated in a microwave oven at 750 $\mathrm{W}$ for $4 \mathrm{~min}$, and the DNA was stained with $25 \mu \mathrm{l}$ of the fluorochrome SYBR Gold (Molecular Probes, Eugene, OR, USA) diluted 1:100 in TBE buffer (0.09 M Tris-borate, $0.002 \mathrm{M}$ EDTA, pH 7.5) for 5 min in the dark.

Images were viewed under an epifluorescence microscope (Nikon E800), with a 100× objective and appropriate fluorescence filters, and the images were acquired using a high-sensitivity CCD camera (KX32ME, Apogee Instruments, Roseville, CA, USA). Groups of 16-bit digital images were obtained at each experimental time under similar conditions and stored as TIFF files. Image analysis 
was performed using a macro designed with Visilog 5.1 software (Noesis, Gif sur Yvette, France). This macro allows for thresholding and background subtraction, and delineates the circular area of diffusion of the DNA fragments from nucleoids. The width delimitated between the edge of the nucleoid and the circumference that limits the circular peripheral area of spreading of DNA fragments is the simplest parameter to estimate DNA fragmentation level after CIP treatment and was measured in $\mu \mathrm{m}$. At each experimental time, 50-125 nucleoids were evaluated.

\section{Statistical analysis}

Because the data did not follow a normal distribution as ascertained by the Kolmogorov-Smirnov test, the nonparametric Mann-Whitney $U$ test was performed to compare the groups. Significance was defined as $P<0.05$.

\section{Results \\ Dose response}

The E. coli strain TG1 (CIP MIC of $0.012 \mu \mathrm{g} / \mathrm{ml}$ ) was exposed to increasing doses of CIP in liquid LB medium for $40 \mathrm{~min}$ at $37^{\circ} \mathrm{C}$ (Fig. 1). Doses less than the MIC did not result is visible DNA fragments, even after increasing the incubation time with the antibiotic to $90 \mathrm{~min}$ (Fig. 1b). The MIC dose resulted in a clear effect: nucleoids appeared compact but with few peripheral DNA fragments (Fig. 1c). As the dose increased, the number of DSBs increased gradually, which was reflected in progressively more DNA fragments and their elevated surface showing peripheral diffusion from the nucleoid (Figs $1 \mathrm{~d}$ and $1 \mathrm{e}$ ). After the 0.5 $\mu \mathrm{g} / \mathrm{ml}$ dose, all nucleoids appeared massively fragmented as small DNA spots that diffused widely from their original place in the bacteria (Fig. 1f). The $1 \mu \mathrm{g} / \mathrm{ml}$ dose resulted in nucleoids that appeared similar to those obtained after 0.5 $\mu \mathrm{g} / \mathrm{ml}$. The degree of fragmentation tended to be homogeneous after each dose, probably because of the relative similarity in the response to the antibiotic between the different bacteria. The DNA fragments always appeared as small spots, independent of the dose.

The width of the dispersion of the fragments from the boundary of the nucleoid was quantified using an image analysis system; this measure is a simple and reliable quantitative parameter that reflects the level of CIPinduced DNA damage (Table 1). Differences were significant between the doses tested from $0.012 \mu \mathrm{g} / \mathrm{ml}$, except between $0.012 \mu \mathrm{g} / \mathrm{ml}$ and $0.02 \mu \mathrm{g} / \mathrm{ml}$, between $0.04 \mu \mathrm{g} /$ $\mathrm{ml}$ and $0.08 \mu \mathrm{g} / \mathrm{ml}$, and between $0.5 \mu \mathrm{g} / \mathrm{ml}$ and $1 \mu \mathrm{g} / \mathrm{ml}$. Using the images obtained, the nucleoids were categorized into five classes of damage, as shown in Fig. 2 and Table 1: class 0: undamaged, dose of 0 to $0.008 \mu \mathrm{g} / \mathrm{ml}$ (Figs 1a and 1b); class I: low damage level, dose of 0.012 or $0.02 \mu \mathrm{g} / \mathrm{ml}$ (Fig. 1c); class II: intermediate level, dose of 0.04 or $0.08 \mu \mathrm{g} / \mathrm{ml}$ (Fig. 1d); class III: high level, dose of $0.1 \mu \mathrm{g} / \mathrm{ml}$ (Fig. 1e); and class IV: massive fragmentation, doses of 0.5 or $1 \mu \mathrm{g} / \mathrm{ml}$ or higher (Fig. 1f). This latter class
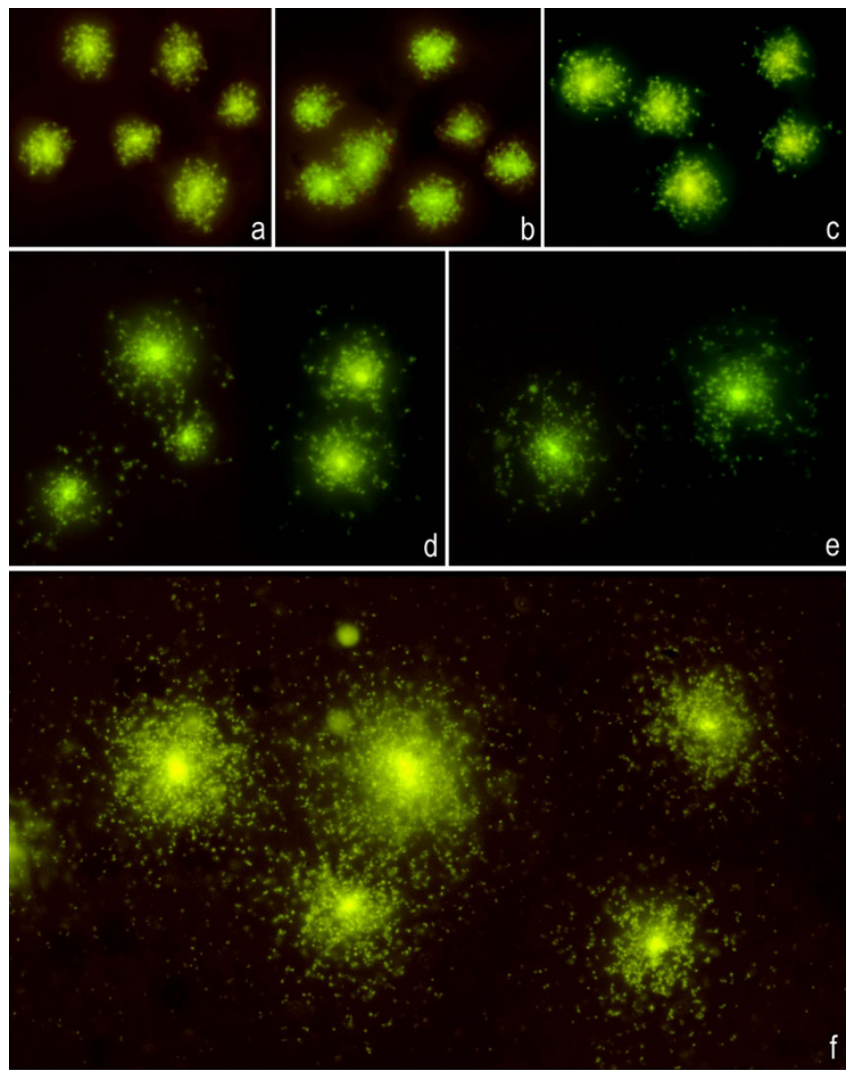

\section{Figure I}

Dose-response effect of CIP on nucleoids from the $E$. coli strain TG I. After 40 min incubation with CIP, the cells were processed with the Micro-Halomax ${ }^{\circledR}$ kit and stained with SYBR Gold. a: Control untreated cells;b: $0.008 \mu \mathrm{g} / \mathrm{ml}$; c: $0.012 \mu \mathrm{g} / \mathrm{ml}$, i.e., the MIC dose; d: $0.04 \mu \mathrm{g} / \mathrm{ml}$; e: $0.1 \mu \mathrm{g} / \mathrm{ml}$; f: $0.5 \mu \mathrm{g} / \mathrm{ml}$.

of damage was practically undistinguishable from that shown by nucleoids with extensive DNA fragmentation always present spontaneously in cultures [15]. Classification into classes is standard practice in mutagenesis studies and provides a perceptive description that is especially useful when heterogeneity in the DNA damage rank is evident between the different nucleoids, as observed in the DNA repair experiments.

\section{Incubation time}

To determine the minimum incubation time needed to detect a DNA-breakage effect, the TG1 E. coli were collected from LB agar and exposed in liquid LB to $1 \mu \mathrm{g} / \mathrm{ml}$ CIP for $0,5,10,15,20,30$, and $40 \mathrm{~min}$. The microgel preparation time before immersion in the lysing solution ( $8 \mathrm{~min}$ ) must be added to these times because the antibiotic may enter the bacteria and act during this period. Detectable but subtle damage was apparent after 0 min (class I: diffusion width $1.7 \pm 0.2 \mu \mathrm{m}$ ) (Fig. 3); this subtle damage appeared as nucleoids with some peripheral DNA fragments unlike in the untreated control cells. As the 
Table I: Dose-response effect of CIP on TGI E. coli chromosomal DNA analyzed with the Micro-Halomax ${ }^{\circledR}$ kit.

\begin{tabular}{|c|c|c|c|}
\hline Dose $(\mu \mathrm{g} / \mathrm{ml})$ & Width of dispersion $(\mu \mathrm{m})$ & Class & Range \\
\hline 0 & - & & \\
\hline 0.003 & - & 0 & 0 \\
\hline 0.006 & - & & \\
\hline 0.008 & - & & \\
\hline 0.012 & $1.3 \pm 0.3$ & 1 & $\leq 2.0$ \\
\hline 0.02 & $1.6 \pm 0.3$ & & \\
\hline 0.04 & $2.5 \pm 0.4$ & II & $2.1-3.7$ \\
\hline 0.08 & $3.3 \pm 0.4$ & & \\
\hline 0.1 & $5.1 \pm 1.0$ & III & $3.8-5.7$ \\
\hline 0.5 & $7.8 \pm 1.4$ & IV & $\geq 5.8$ \\
\hline I & $8.8 \pm 1.6$ & & \\
\hline
\end{tabular}

The width of the halo of dispersion of DNA fragments is presented in $\mu \mathrm{m}$ (mean \pm standard deviation). The extent of DNA damage was classified according to the width of the dispersion.

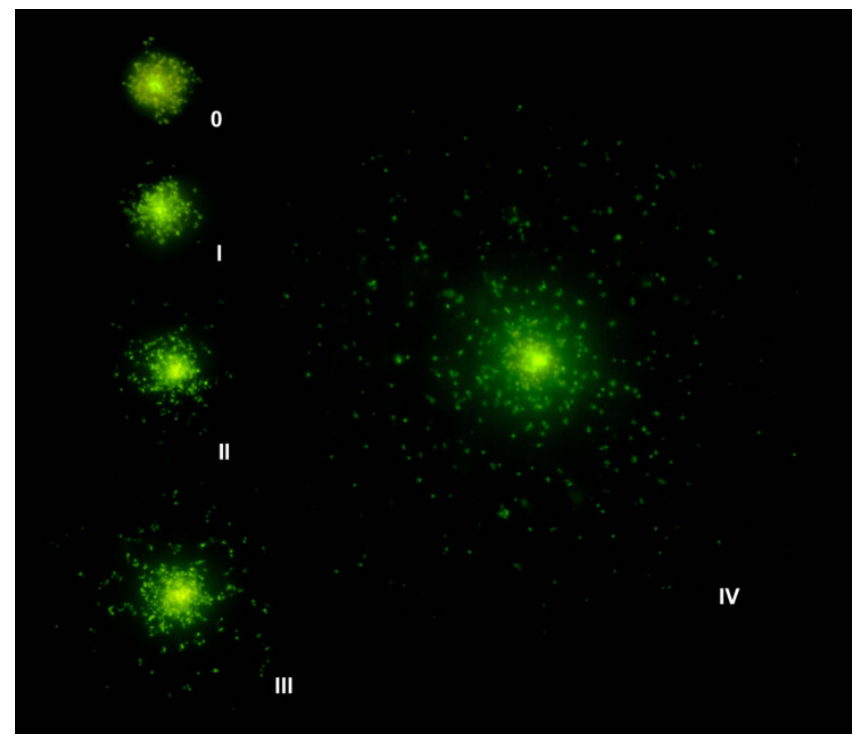

Figure 2

Nucleoids from $E$. coli strain TG I with progressively increased DNA fragmentation after incubation with increasing doses of CIP. 0: undamaged; I: low damage level; II: intermediate damage; III: high damage level; IV: massive fragmentation.

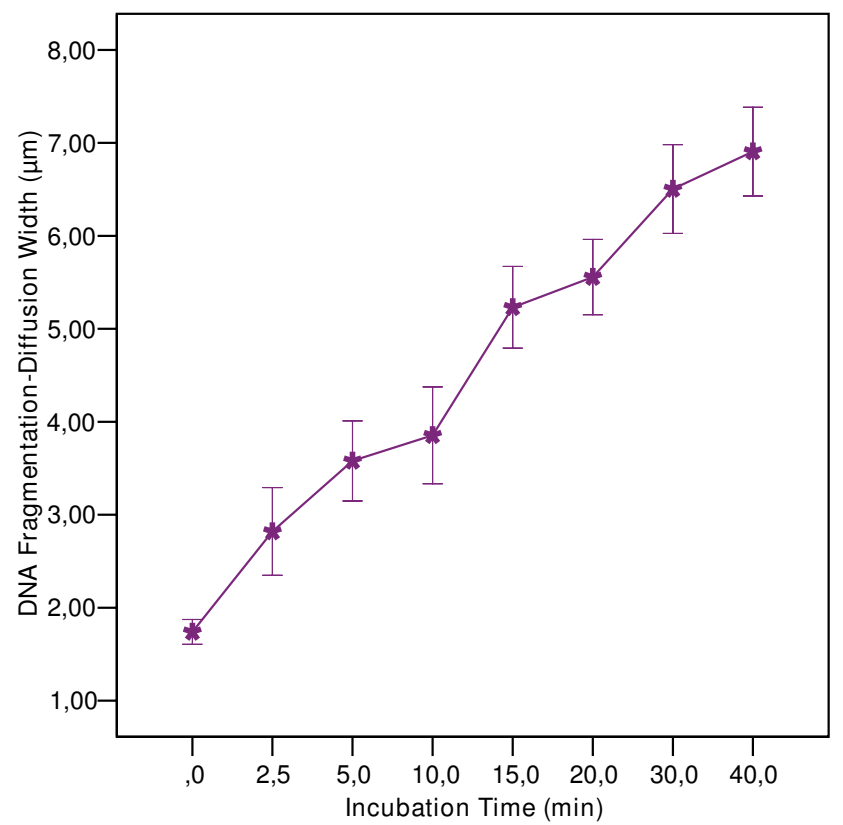

Figure 3

Effect of the incubation time at a dose of I $\mu \mathrm{g} / \mathrm{ml}$ of CIP. The DNA fragmentation level is categorized by the width of the halo of diffusion of the DNA fragments emerging from nucleoids of $E$. coli strain TGI.

incubation time increased, the level of DNA damage increased progressively to class II after $2.5 \mathrm{~min}(2.8 \pm 1.0$ $\mu \mathrm{m})$ and class III after $15 \mathrm{~min}(5.2 \pm 1.0 \mu \mathrm{m})$; nucleoids appeared massively fragmented after $30 \mathrm{~min}$ (class IV, 6.5 $\pm 1.1 \mu \mathrm{m}$ ) (Fig. 3). As in the dose-response study, the DNA damage intensity also tended to be homogeneous in the different nucleoids at each sample time.

The DNA fragmentation level did not differ between bacteria incubated with the antibiotic at room temperature or at $37^{\circ} \mathrm{C}$, or with or without agitation. Interestingly, TG1 grown previously in LB broth instead of LB agar and tested in the exponentially growing phase produced the most DNA fragmentation (class IV) after 0 min; i.e., immediately after the $8 \mathrm{~min}$ of microgel preparing.

To investigate why the DNA damage level was dependent on the previous culture conditions, TG1 was grown in LB broth for $23 \mathrm{~h}$, and the $\mathrm{OD}_{600}$ was monitored. Aliquots were removed after different culture times and incubated with $1 \mu \mathrm{g} / \mathrm{ml}$ CIP for 0 and $5 \mathrm{~min}$ (adding the $8 \mathrm{~min}$ of microgel preparation) (Fig. 4). After $3 \mathrm{~h}$ of culture (i.e., in the exponentially growing phase), all nucleoids were class IV after 0 and $5 \mathrm{~min}$, as described above. After $7 \mathrm{~h}$, the culture had achieved the stationary phase, and the nucleoids appeared mainly as class II (89.4\%) and a few of them as class I after 0 min of incubation, whereas most $(97.8 \%)$ 

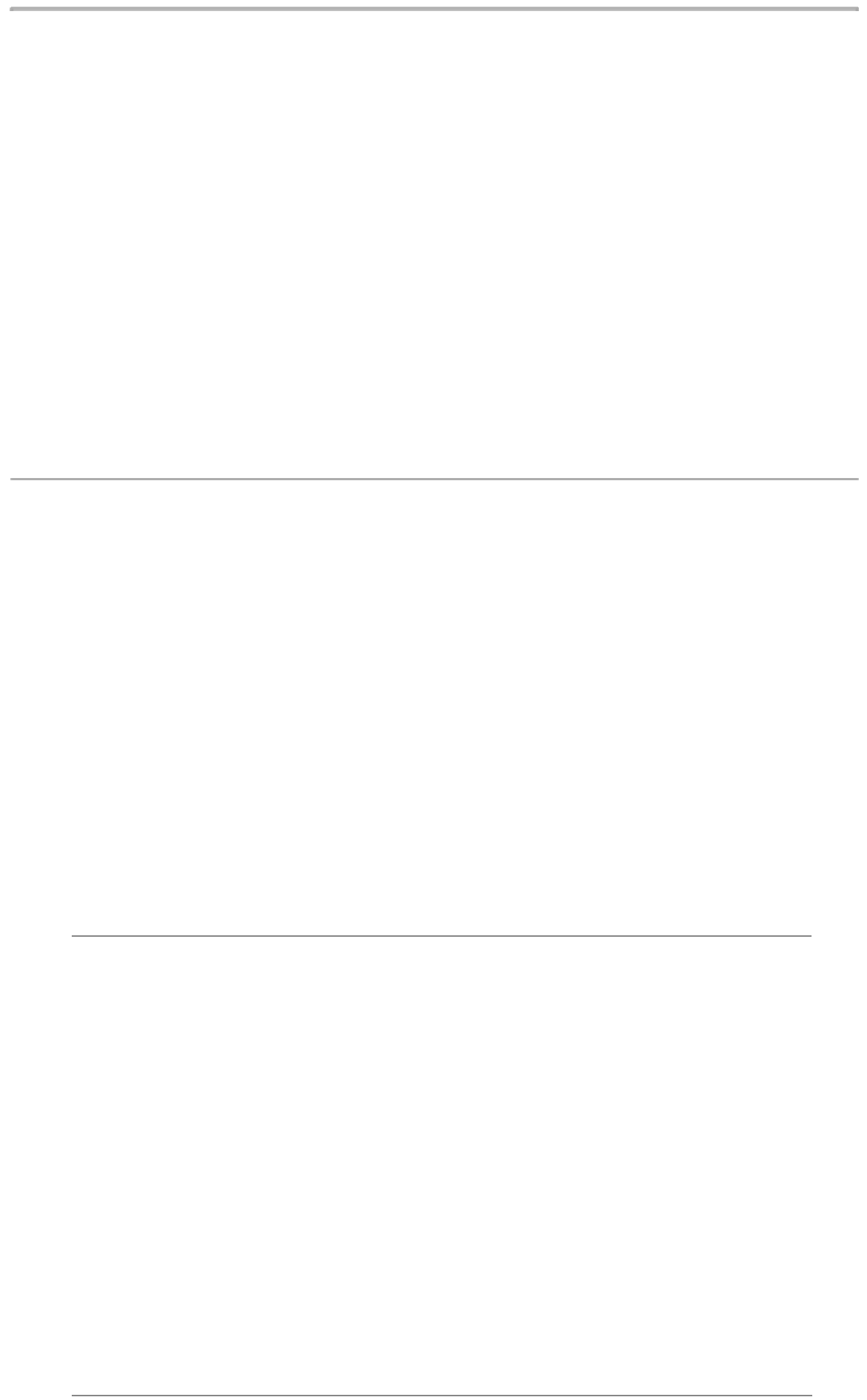

\section{Figure 4}

DNA fragmentation in nucleoids from E. coli strain TGI exposed to CIP in different culture times. The growth curve of the bacteria, evaluated by monitoring turbidity at $\mathrm{OD}_{600}$, is presented above. The distribution of the frequencies of the diffusion widths of DNA fragments from the nucleoids were categorized into the five classes 0 to IV described in Table I and Fig. 2. Aliquots from a batch culture were removed at $3 \mathrm{~h}$ (exponentially growing phase) and at 7, 9, and $23 \mathrm{~h}$ (stationary phase), incubated with I $\mu \mathrm{g} / \mathrm{ml} \mathrm{CIP}$ for 0 (i.e., technical processing time of $8 \mathrm{~min}$ ) (medium) and $5 \mathrm{~min}$ (below), and then processed to determine the DNA fragmentation. 
were class IV after $5 \mathrm{~min}$. Aliquots removed after $9 \mathrm{~h}$ (i.e., stationary phase) showed nucleoids as classes I (84.0\%) and $0(16.0 \%)$ after $0 \mathrm{~min}$, and class III $(98.4 \%)$ after 5 min incubation with CIP. The same result occurred after $23 \mathrm{~h}$ of culture. This experiment suggests that the growing conditions influence the speed of the CIP effect, which becomes increasingly slower when the bacteria are progressing into the stationary phase.

\section{Evolution of DNA damage}

The TG1 E. coli strain was exposed to three different doses of CIP, 10, 1, and $0.1 \mu \mathrm{g} / \mathrm{ml}$, for $40 \mathrm{~min}$. After this treatment, the antibiotic was washed out, and the bacteria were incubated for $0,1.5,3,4,5$, and $24 \mathrm{~h}$ (Fig. 5).
After exposure to the highest dose $(10 \mu \mathrm{g} / \mathrm{ml})$, all nucleoids were extremely fragmented, i.e., class IV. The DSB repair was limited and clearly noticeable only after $4 \mathrm{~h}$; $82.5 \%$ of nucleoids were of class III after $5 \mathrm{~h}$. Remarkably, all the nucleoids from the bacteria observed after $24 \mathrm{~h}$ showed massive fragmentation (class IV). Viability was very low after $0,1.5,3$, and $4 \mathrm{~h}$, and zero after 5 and $24 \mathrm{~h}$ (Fig. 5a).

Immediately after incubating with the $1 \mu \mathrm{g} / \mathrm{ml}$ dose, all nucleoids were class IV. A higher repair level was observed than after the highest dose, predominantly class III $(58.7 \%)$ after $4 \mathrm{~h}$, class I (41.0\%) after $5 \mathrm{~h}$, and class I (47.1\%) after $24 \mathrm{~h}$. Apparently repaired nucleoids with-
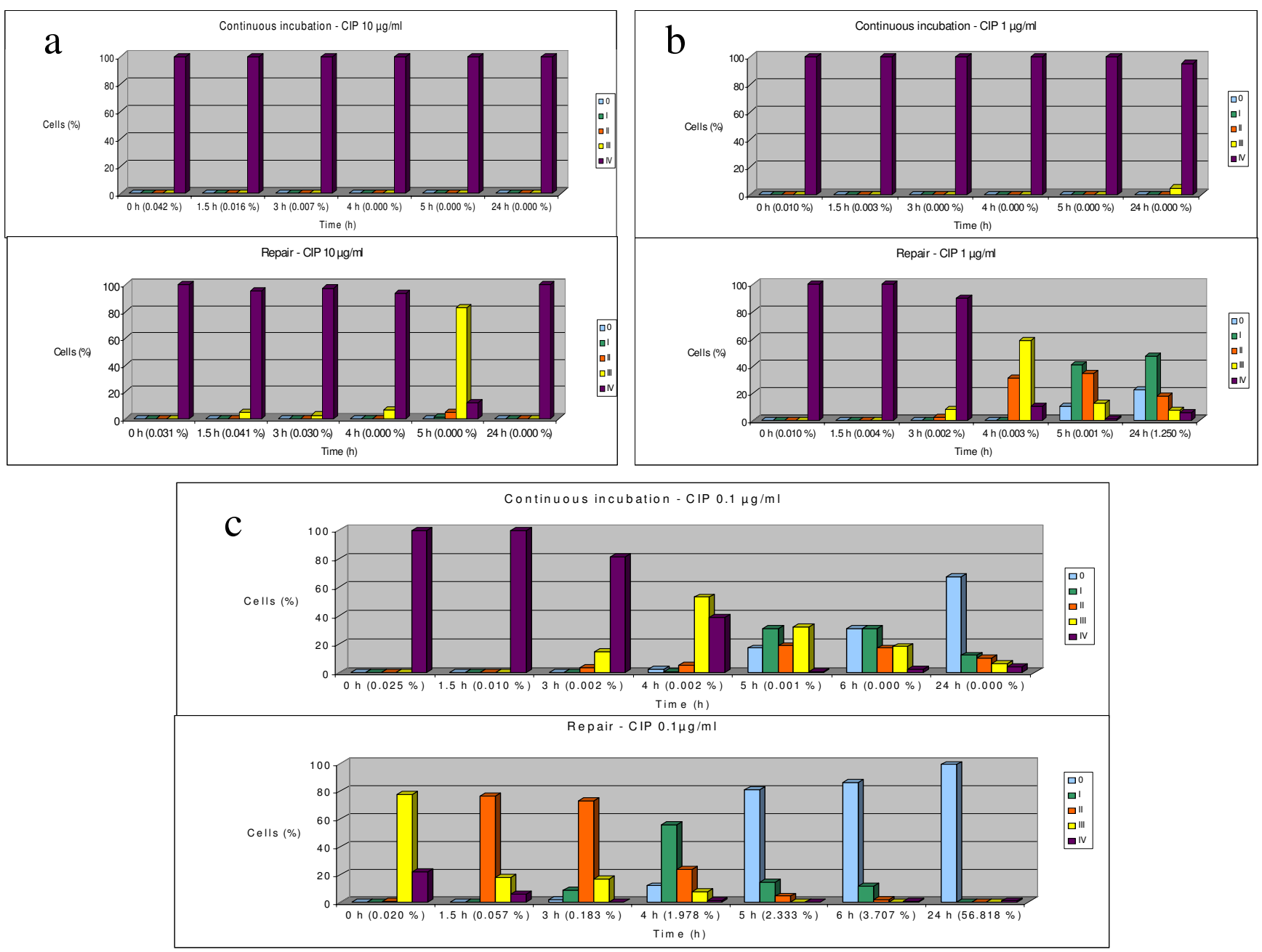

Figure 5

Repair of CIP ( $10 \mu \mathrm{g} / \mathrm{ml})$ induced DNA fragmentation. The distribution of the frequencies of the diffusion widths from the nucleoids were categorized according to the five classes of fragmentation level ( 0 to IV) presented in Table I and Fig. 2. The different repair times after exposure of TGI E. coli to three doses of CIP (a: $10 \mu \mathrm{g} / \mathrm{ml}, \mathbf{b}: \mathrm{I} \mu \mathrm{g} / \mathrm{ml}$, and c: $0.1 \mu \mathrm{g} / \mathrm{ml}) \mathrm{for} 40$ min are presented. Viability (\%) is indicated next to each repair time. Each dose is shown with its respective culture (above) in which the antibiotic was present during the incubation time. 
out diffusing DNA fragments (10.2\%) were visualized after $5 \mathrm{~h}$, and this increased to $22.2 \%$ after $24 \mathrm{~h}$. However, the viability was very low, as in the experiment with the highest dose (Fig. 5b).

In contrast to the results at the higher doses, repair activity was evident in the cultures exposed continuously to 0.1 $\mu \mathrm{g} / \mathrm{ml}$ of CIP for the various times (Fig. 5c); $53.0 \%$ of nucleoids were class III after $4 \mathrm{~h}$, and $31 \%$ were class I and $31 \%$ class 0 after $6 \mathrm{~h}$. This latter time was assessed further in this experiment. The frequency of class 0 increased from $2.3 \%$ after $4 \mathrm{~h}$ to $67.3 \%$ after $24 \mathrm{~h}$. In all cases, viability was very low or zero. Removing the drug resulted in faster repair kinetics, predominantly of class II (76.2\%) after $1.5 \mathrm{~h}$ and class $0(81.0 \%)$ after $5 \mathrm{~h}$ (Fig. $5 \mathrm{c}$ ). The nucleoid pattern was similar to that of the untreated control cells after $24 \mathrm{~h}$. Viability was initially very low, 2-4\% after $4-6 \mathrm{~h}$, and increased to $56.8 \%$ after $24 \mathrm{~h}$ (Fig. 5c). Thus, we found no clear relationship between the extent of repair of CIP-induced DNA breakage and cell viability.

\section{Evaluation of strains with known mechanisms of low sensitivity to CIP}

The other E. coli strains used have been described previously [16]. They include strains with one amino acid substitution mutation in GyrA (C-15), two substitution mutations in GyrA (1273), and two substitution mutations in GyrA and another two in ParC (1383). The more mutations, the greater the resistance level, as reflected in the MIC values (Table 2). We also evaluated a strain with a qnrA1 plasmid (J53 qnrA1) [17] (Table 2). Doses lower than the MIC never resulted in visible DNA fragments. Thus, in strains with a MIC of $0.25 \mu \mathrm{g} / \mathrm{ml}$ (C-15 and J53 qnrA1), the MIC dose caused little DNA fragmentation in all bacteria (class I), whereas doses of $10 \times$ and $100 \times$ the MIC caused massive DNA fragmentation (class IV) (Table
2; Fig. 6). This behaviour is similar to that of the fully sensitive control strains but was shifted to a higher MIC. The 1273 strain did not show a clear effect at the MIC dose (8 $\mu \mathrm{g} / \mathrm{ml}$ ) but appeared as class I after $10 \times$ and class II after $100 \times$ of the MIC dose (Table 2; Fig. 7). The 1383 strain has a high MIC $(128 \mu \mathrm{g} / \mathrm{ml})$ and showed no DNA damage at any dose (Table 2; Fig. 7).

\section{Discussion}

CIP-induced chromosomal DNA fragmentation was assayed in situ in E. coli using the Micro-Halomax ${ }^{\circledast}$ kit [15]. We grew the samples in LB agar because this is simpler and is used routinely in clinical microbiology laboratories. The sample is scratched, diluted in LB broth to an $\mathrm{OD}_{600}$ of 0.05 , and incubated with CIP in $4 \mathrm{ml}$ of liquid $\mathrm{LB}$ in a $15 \mathrm{ml}$ Falcon tube at $37^{\circ} \mathrm{C}$ with aeration. Incubation in a $1.5 \mathrm{ml}$ Eppendorf tube with $24 \mu \mathrm{l}$ of LB broth at room temperature $\left(22^{\circ} \mathrm{C}\right)$ and without aeration does not modify the kinetics of DNA fragmentation induced by 1 $\mu \mathrm{g} / \mathrm{ml}$ of CIP. We observed similar results in the TG1 strain and in three other E. coli-sensitive samples. Further confirmation in other sensitive strains could simplify the protocol for assessing E. coli sensitivity or resistance to CIP in the clinic.

Incubating TG1 with CIP for $40 \mathrm{~min}$ before technical processing produced a clear dose-response effect in chromosomal DNA fragmentation, and the damage level was similar in the different nucleoids. The effect on DNA was evident starting at the MIC dose, and DNA fragments were always visualized as spots of relatively small size, independently of the dose. The fragment size after oxolinic acid or norfloxacin treatment of $E$. coli has been estimated at 50 to $100 \mathrm{~kb}$; i.e., the presumed size of the DNA loops of the nucleoid [18-20]. Our result suggests that the DNA fragments liberated from the nucleoid are of fairly regular

Table 2: DNA fragmentation levels obtained in strains of $E$. coli with different susceptibilities to CIP.

\begin{tabular}{|c|c|c|c|c|c|}
\hline \multirow[b]{2}{*}{ Strain } & \multirow[b]{2}{*}{ Mutations } & \multirow[b]{2}{*}{ MIC } & \multicolumn{3}{|c|}{ CIP dose } \\
\hline & & & MIC IX & MIC IOx & MIC I00x \\
\hline C-20 & - & 0.007 & $1.5 \pm 0.3$ & $6.7 \pm 0.8$ & $10.3 \pm 2.5$ \\
\hline C- 15 & Ser83Leu from GyrA & 0.25 & $1.7 \pm 0.3$ & $6.2 \pm 0.7$ & $8.7 \pm 1.1$ \\
\hline 1273 & Ser83Leu and Asp87Tyr from GyrA & 8 & 0 & $1.8 \pm 0.3$ & $2.7 \pm 0.4$ \\
\hline 1383 & Ser83Leu and Asp87Tyr from GyrA and Ser80lle and Glu84Lys from ParC & 128 & 0 & 0 & 0 \\
\hline J53 & - & 0.007 & $1.8 \pm 0.8$ & $9.2 \pm 1.2$ & $10.4 \pm 2.0$ \\
\hline J53qnrAI & Plasmid gene J53qnrAI & 0.25 & $1.9 \pm 0.4$ & $9.5 \pm 1.3$ & $9.8 \pm 0.9$ \\
\hline
\end{tabular}

The level of fragmentation obtained by different CIP doses is indicated by the width of the halo of dispersion of DNA fragments and is measured in $\mu \mathrm{m}$ (mean \pm standard deviation). MIC is in $\mu \mathrm{g} / \mathrm{ml}$. 


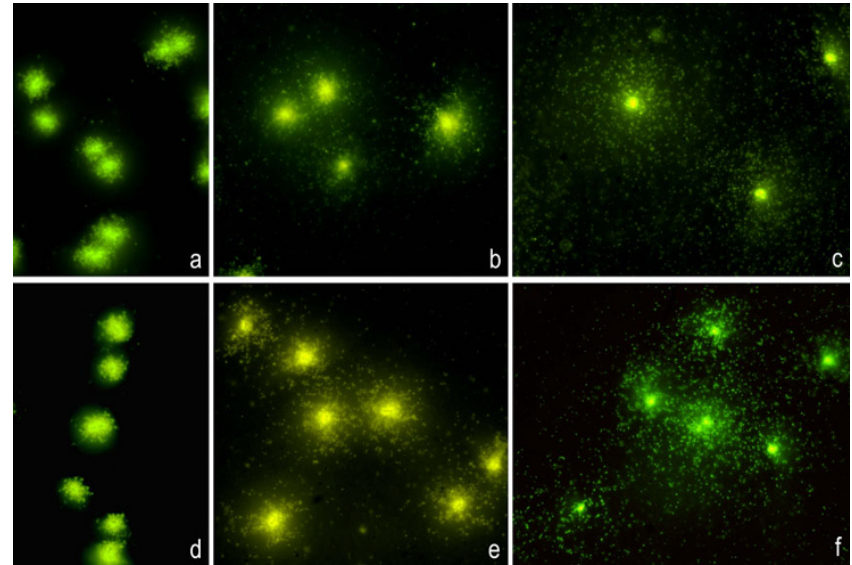

Figure 6

Representative images of the DNA fragmentation induced by CIP in E. coli strains C-20 and C-I 5. Left: MIC dose; medium: I0× MIC dose; right: 100× MIC dose. Above: control C-20 strain. a: $0.007 \mu \mathrm{g} / \mathrm{ml}$; b: $0.07 \mu \mathrm{g} / \mathrm{ml}$; c: $0.7 \mu \mathrm{g} / \mathrm{ml}$. Below: C-I 5 strain. d: $0.25 \mu \mathrm{g} / \mathrm{ml}$;e: $2.5 \mu \mathrm{g} / \mathrm{ml}$; f: $25 \mu \mathrm{g} / \mathrm{ml}$.

size and that more fragments are released as the CIP dose increases. It also supports the possibility of clusters of preferential DNA gyrase cleavage sites [19]. It is possible that doses smaller than the MIC could induce a small amount of DSBs, which could be spaced widely in the different domains but not cause spreading of the fragments.

In our previous report, a CIP dose of $0.012 \mu \mathrm{g} / \mathrm{ml}$ produced slightly more damage than in the present study
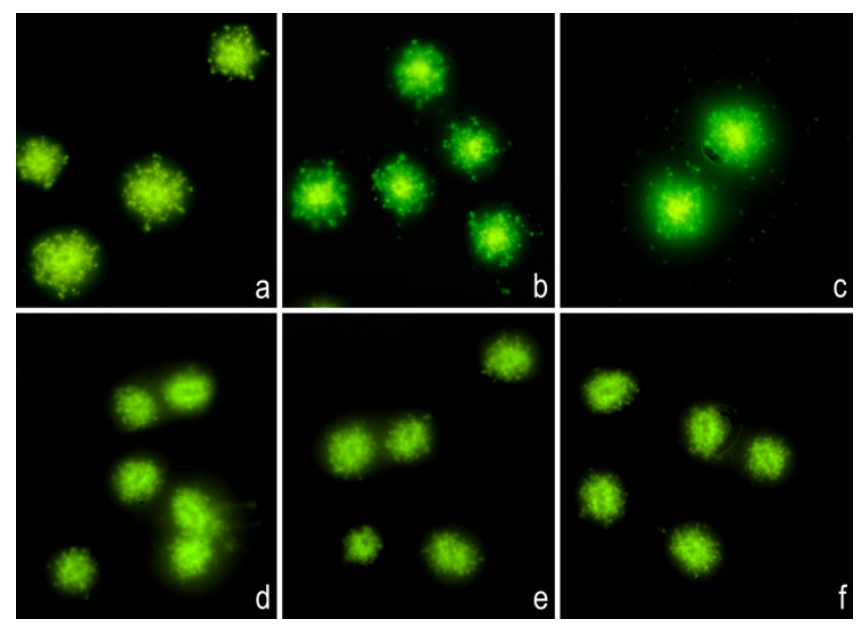

Figure 7

Representative images of the DNA fragmentation induced by CIP in E. coli I 273 and I 383 strains. Left: MIC dose; medium: I0× MIC dose; right: 100× MIC dose. Above: 1273 strain. a: $8 \mu \mathrm{g} / \mathrm{ml}$; b: $80 \mu \mathrm{g} / \mathrm{ml}$; c: $800 \mu \mathrm{g} / \mathrm{ml}$. Below: I 383 strain. d: I $28 \mu \mathrm{g} / \mathrm{ml}$; e: $1280 \mu \mathrm{g} / \mathrm{ml}$; f: I 2800 $\mu \mathrm{g} / \mathrm{ml}$.
[15]. This is probably because of the harsher lysing conditions in our previous study, which may have caused additional DNA damage. This was corrected in the conditions used in our current study.

Adding $1 \mu \mathrm{g} / \mathrm{ml}$ of CIP to TG1 in LB broth and instantaneous processing using our technique produced just barely detectable DNA fragmentation. Taking TG1 from LB agar reduces the extent of damage. DNA damage increases progressively with incubation time, and a $30 \mathrm{~min}$ incubation is needed to achieve the maximum level of DNA fragmentation. Remarkably, when the bacteria came from exponentially growing cultures in LB broth, the highest DNA fragmentation level was observed immediately ( $0 \mathrm{~min})$. These results suggest that the CIP effect on DNA is cumulative with time and that its velocity is dependent on the growing conditions. We confirmed this hypothesis by analyzing aliquots removed periodically from a batch culture incubated with $1 \mu \mathrm{g} / \mathrm{ml}$ CIP for 0 and $5 \mathrm{~min}$. The DNA fragmentation level declined progressively as the bacteria proceed into the stationary phase.

Most E. coli cells divide uniformly in exponentially growing cultures but stop dividing when they achieve the stationary phase [21]. Bacteria grown in LB agar should be heterogeneous with regard to the growing phase, both exponential and stationary. The MIC is an average of the bacterial sensitivity to the antibiotic, which reflects the different effect of CIP on DNA. The DNA fragmentation yield is homogeneous among the nucleoids in exponentially growing TG1 but is slower and tends to be more heterogeneous in the stationary phase. This greater heterogeneity was evident after short incubation with 1 $\mu \mathrm{g} / \mathrm{ml}$ CIP but tended to be homogeneous after $40 \mathrm{~min}$ of treatment.

Pulse field gel electrophoresis shows that the norfloxacininduced fragmentation in E. coli nucleoids is low in the stationary phase of growth [20]. This phenomenon could reflect decreased drug uptake, increased drug efflux, downregulation of topoisomerases, or a more tightly packed nucleoid structure as demonstrated by atomic force microscopy [22]. Using our procedure, we have also observed more compacted nucleoids in the stationary phase. The most probable explanation is the activation of multidrug transporters that exclude fluoroquinolones, which is mediated by quorum-sensing signals. In fact, the quorum-sensing transcription factor SdiA from E. coli is regulated in a density-dependent manner, and its overproduction upregulates $A c r A B$, which increases resistance to quinolones and other antibiotics [23].

The lysing solution causes protein denaturation, so theoretically, the sensitivity-resistance assay is adequate to investigate sensitivity to fluoroquinolones at the relevant 
doses. CIP-mediated DSBs are natively unconstrained and are considered irreversible and lethal. In the case of firstgeneration quinolones such as nalidixic acid, the technique would artificially unconstrain DSBs that are naturally confined in the cleaved complex. If so, both reversible non-lethal DSBs and later lethal unconstrained DSBs should be detected without but cannot be differentiated in the assay. Addition of the chelating agent EDTA seems to reverse the cleaved complex formation by quinolones [7], possibly because incubation with EDTA before lysis allows the resealing of the reversible DNA breaks so that only the irreversible DSBs would be detected.

CIP-induced DSBs were not totally irreversible, and a progressive repair activity with time was evident in TG1. The magnitude of DNA repair was inversely related to dose and was noticeable after a dose of $0.1 \mu \mathrm{g} / \mathrm{ml}$ but scarce after a dose of $10 \mu \mathrm{g} / \mathrm{ml}$. This repair was evident when the antibiotic was removed after the $40 \mathrm{~min}$ incubation and when TG1 was exposed continuously to the low dose (0.1 $\mu \mathrm{g} / \mathrm{ml}$ ) without CIP removal. The progressive spontaneous CIP degradation or inactivation with time in culture cannot be discounted, and the effect of CIP could be smaller despite being long lasting, especially if added at a low dose.

E. coli may repair DSBs by RecA-dependent homologous recombination (HR) [24]. CIP-induced DSBs could be processed to single-stranded DNA, a target for RecA, which promotes recombinatorial repair and induction of the SOS response through activation of the autocleavage of the LexA repressor $[25,26]$. Rapid lethality is increased by the lexA Ind-allele, and recombination-deficient $E$. coli strains are hypersensitive to quinolones [27]. The RecBCD nuclease/helicase also seems to be required for SOS induction by quinolones, as demonstrated with nalidixic acid [28]. Interestingly, DSBs may also be repaired by a non-homologous end joining (NHEJ) mechanism that comprises break recognition, end processing, and ligation activities. Although E. coli lacks a NHEJ pathway, its presence has been demonstrated in mycobacteria and bacillus [29]. Nevertheless, NHEJ deficiency caused by the loss of $\mathrm{Ku}$ and ligD has no effect on the sensitivity to quinolones of Mycobacterium smegmatis [30].

Repair of quinolone-induced DSBs probably needs more complex processing because both $5^{5}$ ends of cleaved DNA are linked covalently via phosphotyrosine bonds to a topoisomerase subunit. These DNA-protein crosslinks (DPCs) could be eliminated in coordination with the nucleotide excision repair (NER) mechanism. The urvABC nuclease, which initiates the NER pathway in E. coli, may incise DPCs with or without previous proteolytic degradation of the crosslinked protein [31]. Accordingly, NER seems to be involved in CIP-induced DNA damage, as demonstrated in deficient E. coli strains [27]. Although both NER and HR may commit to the repair of DPCs, it has been proposed recently that DPCs with crosslinked proteins of sizes $<12-14 \mathrm{kDa}$ are repaired by NER, whereas oversized DPCs are processed exclusively by RecBCD-dependent HR [32]. If confirmed, the later mechanism should be preferred in the repair of DPCs involving topoisomerase subunits.

The repair activity was not strictly related to viability. Although the nucleoid may appear normal after repair, particularly at the low dose $(0.1 \mu \mathrm{g} / \mathrm{ml})$, the bacteria may not be fully viable, possibly because of the lack of total fidelity in restitution and the SOS response, resulting in an error-prone repair [26]. Some misrepaired lesions could lead to a non-viable cell. The DNA repair experiments emphasize the importance of achieving the necessary concentrations over a prolonged time for the successful clinical effect of quinolones.

DNA repair is not cited as a mechanism of decreased sensitivity to quinolones. Nevertheless, E. coli mutants with constitutive RecA expression or defective SOS induction may survive longer [27]. It is possible that dysfunction of certain DNA repair processes may lead to a low sensitivity to CIP, and this could increase the effect of other coexisting mechanisms of resistance. This possibility needs to be explored.

It is expected that resistance to fluoroquinolones would hinder the production of DSBs, which are slowly or rarely produced. Because DSBs appear to correlate strongly with the MIC and viability, the DNA fragmentation assay should detect resistance accurately. The preliminary study of the DNA fragmentation analysis in the four E. coli strains with low sensitivity to CIP suggests that this is the case. The 1273 strain did not show a clear effect at the MIC dose and had a lower DNA fragmentation level than that observed in other strains at the same multiple of MIC dose. This phenomenon could be related to the accumulation of multiple resistance mechanisms, such as multiple mutations in different topoisomerase subunits and in conjunction with altered outer membrane proteins and lipopolysaccharide, and increased activity of efflux systems [33]. Since only J-53 and J-53qnrA1 strains are isogenic, the other strains could have other differences that could influence the results. Moreover, the growth inhibition may not be dependent on inhibition of the topoisomerases leading to DNA fragmentation and the possibility exists of unknown mechanisms of action.

\section{Conclusion}

The DNA fragmentation assay may be a simple and rapid test to evaluate the sensitivity and resistance to quinolo- 
nes. We are currently performing more comprehensive assessment of different characterized CIP-resistant and CIP-sensitive E. coli strains and in clinical samples.

\section{Authors' contributions}

MT and RB performed technical experiments and statistical analysis. JG participated in image acquisition and image analysis. GB participated in the design of the study and data analysis. JLF conceived the study, participated in its design and coordination and wrote the initial draft of the manuscript. All authors read and approved the final manuscript.

\section{Acknowledgements}

This work was supported by a public grant from the Xunta de Galicia 07CSA0509|6PR and INCITE08EIR916070ES, and by FIS PI06/368.

\section{References}

I. Appelbaum PC, Hunter PA: The fluoroquinolone antibacterials: past, present and future perspectives. Int J Antimicrob Agents 2000, 16(I):5-15.

2. Emmerson AM, Jones AM: The quinolones: decades of development and use. J Antimicrob Chemother 2003, 5 I (Suppl I): I3-20.

3. Champoux J]: DNA topoisomerases: structure, function, and mechanism. Annu Rev Biochem 200I, 70:369-4I3.

4. Corbett KD, Berger JM: Structure, molecular mechanisms, and evolutionary relationships in DNA topoisomerases. Annu Rev Biophys Biomol Struct 2004, 33:95-1 I8.

5. Drlica K, Zhao X: DNA gyrase, topoisomerase IV, and the 4quinolones. Microbiol Mol Biol Rev 1997, 6 I (3):377-392.

6. Drlica K, Malik M, Kerns RJ, Zhao X: Quinolone-mediated bacterial death. Antimicrob Agents Chemother 2008, 52(2):385-392.

7. Malik $M$, Zhao $X$, Drlica $K$ : Lethal fragmentation of bacterial chromosomes mediated by DNA gyrase and quinolones. Mol Microbiol 2006, 6 I (3):8I 0-825.

8. Dwyer DJ, Kohanski MA, Hayete B, Collins JJ: Gyrase inhibitors induce an oxidative damage cellular death pathway in Escherichia coli. Mol Systems Biol 2007, 3:91.

9. Kohanski MA, Dwyer DJ, Hayete B, Lawrence CA, Collins JJ: A common mechanism of cellular death induced by bactericidal antibiotics. Cell 2007, I30(5):797-8I0.

10. Hooper DC: Emerging mechanisms of fluoroquinolone resistance. Emerg Infect Dis 200I, 7(2):337-4I.

II. Hawkey PM: Mechanisms of quinolone action and microbial response. J Antimcrob Chemother 2003, 5 I ( I):29-35.

12. Chen F-J, Lo H-J: Molecular mechanisms of fluoroquinolone resistance. J Microbiol Immunol Infect 2003, 36(I): I-9.

13. Robicsek A, Jacoby GA, Hooper DC: The worldwide emergence of plasmid-mediated quinolone resistance. Lancet Infect Dis 2006, 6(10):629-640.

14. Robiseck A, Strahilevitz J, Jacoby GA, Macielag M, Abbanat D, Park $\mathrm{CH}$, Bush K, Hooper DC: Fluoroquinolone-modifying enzyme: a new adaptation of a common aminoglycoside acetyltransferase. Nat Med 2006, I 2(I):83-88.

15. Fernández JL, Cartelle M, Muriel L, Santiso R, Tamayo M, Goyanes V, Gosálvez ], Bou G: DNA fragmentation in microorganism assessed in situ. Appl Environ Microbiol 2008, 74(19):5925-5933.

16. Vila J, Ruiz J, Goñi P, Jimenez de Anta M: Detection of mutations in parC in quinolone-resistant clinical isolates of Escherichia coli. Antimicrob Agents Chemother 1996, 40(2):49|-493.

17. Martínez-Martínez M, Pascual A, Jacoby GA: Quinolone resistance from a transferable plasmid. Lancet 1998, 35 I (9 I 05):797-799.

18. Snyder M, Drlica K: DNA gyrase on the bacterial chromosome: DNA cleavage induced by oxolinic acid. J Mol Biol 1979, I 3 I (2):287-302.

19. Condemine, Smith CL: Transcription regulates oxolinic acidinduced DNA gyrase cleavage at specific sites on the $E$. coli chromosome. Nucleic Acids Res 1990, I 8(24):7389-7396.
20. Hsu Y-H, Chung M-W, Li T-K: Distribution of gyrase and topoisomerase IV on bacterial nucleoid: implications for nucleoid organization. Nucleic Acids Res 2006, 34(10):3 I 28-3 I38.

21. Roostalu J, Joers A, Luidalepp H, Kaldalu N, Tenson T: Cell division in Escherichia coli cultures monitored at single cell resolution. BMC Microbiol 2008, 8:68.

22. Kim J, Yoshimura SH, Hizume K, Ohniwa RL, Ishihama A, Takeyasu K Fundamental structural units of the Escherichia coli nucleoid revealed by atomic force microscope. Nucl Acids Res 2004, 32(6): 1982-1992.

23. Yang S, Lopez CR, Zechiedrich EL: Quorum sensing and multidrug transporters in Escherichia coli. Proc Natl Acad Sci USA 2006, I03(7):2386-2391.

24. Krasin F, Hutchinson F: Repair of DNA double-strand breaks in Escherichia coli, which requires recA function and the presence of a duplicate genome. J Mol Biol 1977, I I 6(I):81-98.

25. Lewin C, Howard B, Ratcliffe N, Smith J: 4-Quinolones and the SOS response. I Med Microbiol I989, 29(2):139-I44.

26. Howard BM, Pinney RJ, Smith JT: Function of the SOS process in repair of DNA damage induced by modern 4-quinolones. Pharmacol 1993, 45(7):658-662.

27. Piddock LJV, Walters RN: Bactericidal activities of five quinolones for Escherichia coli strains with mutations in genes encoding the SOS response or cell division. Antimicrob Agents Chemother 1992, 36(4):819-825.

28. Newmark KG, O'Reilly EK, Pohhaus JR, Kreuzer KN: Genetic analysis of the requirements for SOS induction by nalidixic acid in Escherichia coli. Gene 2005, 356:69-76.

29. Pitcher RS, Brissett NC, Doherty AJ: Nonhomologous end-joining in bacteria: a microbial perspective. Annu Rev Microbiol 2007, $61: 259-282$

30. Stephanou NC, Gao F, Bongiorno P, Ehrt S, Schnappinger D, Shuman $S$, Glickman MS: Mycobacterial nonhomologous end joining mediates mutagenic repair of chromosomal double-strand DNA breaks. J Bacteriol 2007, I 89( I 4):5237-5246.

31. Minko IG, Zou Y, Lloyd RS: Incision of DNA-protein crosslinks by UrvABC nuclease suggests a potential repair pathway involving nucleotide excision repair. Proc Natl Acad Sci USA 2002, 99(4): 1905-1909.

32. Nakano T, Morishita S, Katafuchi A, Matsubara M, Horikawa Y, Terato $H$, Salem AMH, Izumi S, Pack SP, Makino K, Ide H: Nucleotide excision repair and homologous recombination systems commit differentially to the repair of DNA-protein crosslinks. Mol Cell 2007, 28(1):147-158.

33. Chenia HF, Pillay B, Pillay D: Analysis of the mechanisms of fluoroquinolone resistance in urinary tract pathogens. J Antimicrob Chemother 2006, 58(6): 1274-1278.

Publish with Biomed Central and every scientist can read your work free of charge

"BioMed Central will be the most significant development for disseminating the results of biomedical research in our lifetime. "

Sir Paul Nurse, Cancer Research UK

Your research papers will be:

- available free of charge to the entire biomedical community

- peer reviewed and published immediately upon acceptance

- cited in PubMed and archived on PubMed Central

- yours - you keep the copyright
BioMedcentral 